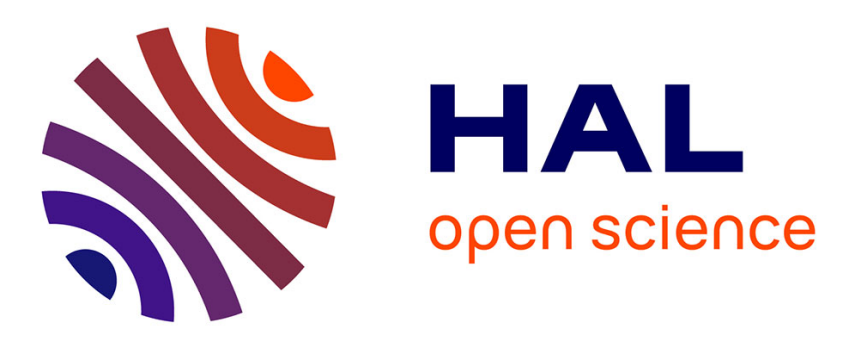

\title{
From Selling Products to Providing User Oriented Product-Service Systems - Exploring Service Orientation in the German Machine and Plant Manufacturing Industry
}

Konstantin Kernschmidt, Stephanie Preissner, Christina Raasch, Birgit Vogel-Heuser

\section{To cite this version:}

Konstantin Kernschmidt, Stephanie Preissner, Christina Raasch, Birgit Vogel-Heuser. From Selling Products to Providing User Oriented Product-Service Systems - Exploring Service Orientation in the German Machine and Plant Manufacturing Industry. 12th IFIP International Conference on Product Lifecycle Management (PLM), Oct 2015, Doha, Qatar. pp.280-290, 10.1007/978-3-319-33111-9_26 . hal-01377452

\section{HAL Id: hal-01377452 \\ https://inria.hal.science/hal-01377452}

Submitted on 7 Oct 2016

HAL is a multi-disciplinary open access archive for the deposit and dissemination of scientific research documents, whether they are published or not. The documents may come from teaching and research institutions in France or abroad, or from public or private research centers.
L'archive ouverte pluridisciplinaire HAL, est destinée au dépôt et à la diffusion de documents scientifiques de niveau recherche, publiés ou non, émanant des établissements d'enseignement et de recherche français ou étrangers, des laboratoires publics ou privés. 


\title{
From selling products to providing user oriented product-service systems - Exploring service orientation in the German machine and plant manufacturing industry
}

\author{
Konstantin Kernschmidt ${ }^{1}$, Stephanie Preißner ${ }^{2}$, \\ Christina Raasch ${ }^{2}$, Birgit Vogel-Heuser ${ }^{1}$ \\ ${ }^{1}$ Institute of Automation and Information Systems, Technische Universität München, Germany \\ \{kernschmidt, vogel-heuser\}eais.mw.tum.de \\ ${ }^{2}$ TUM School of Management, Technische Universität München, Munich, Germany \\ $\{$ s.preissner, c.raasch\} etum. de
}

\begin{abstract}
Companies shifting from selling technical products towards offering integrated product-service systems (PSS) need to extend their existing service portfolio according to their customers' needs. Using a qualitative case study approach this paper explores service orientation in the German machine and plant manufacturing industry. We develop a measure for firm service orientation based on interview and secondary data. We assess the firms' status quo of PSS development and allocate companies on a continuum from product- to result- oriented PSS. Our results indicate that service orientation varies substantially across firms and that a high service orientation is related to a high level of user integration. With regard to product portfolio, we find, that individualized or modularized product architectures foster the development of a higher service orientation. This paper contributes to the understanding of how product and service characteristics need to be intertwined when developing integrated PSS. User integration is identified as an instrument for enhancing service orientation. This paper provides guidance about how to overcome common barriers to enhancing service orientation and shifting from technical products to result-oriented PSS.
\end{abstract}

Keywords: Product-Service System, User integration, Service orientation

\section{$1 \quad$ Introduction}

For a long time, the production of innovative and high-quality products was the primary focus of industrial companies. By extending the product through corresponding services to an integrated product-service system (PSS), manufacturers can offer more sophisticated solutions to user requirements and achieve advantages compared to competitive products [1]. Offering PSS shifts the business focus from selling products to delivering enhanced customer / user utility through the provision of an integrated bundle of product and service components directly targeting user needs. To successfully

adfa, p. 1, 2011.

(C) Springer-Verlag Berlin Heidelberg 2011 
offer PSS, firms need to align their service portfolio with both their existing product portfolio and with their customers' needs [2]. The right services have to be provided and managed over the entire lifecycle of the PSS.

Within this paper, we explore the degree of service orientation and PSS-development in the German machine and plant manufacturing industry by analyzing seven in-depth case studies. Our objectives are threefold: First, we explore variance in service orientation across our sample. Second, due to the proximity of services to actual use experience, we connect firms' service orientation to the integration of user knowledge in PSS development. Third, we aim to explore how different types of product architectures affect companies' service orientation. This paper contributes to the understanding of how product and service characteristics need to be intertwined when developing integrated PSS. Firm service orientation is affected by the existing product portfolio. Also, user integration is identified as an instrument for enhancing service orientation, since service components are directly tied to user experience. Our paper provides guidance about how to manage and overcome common barriers to enhancing service orientation and shifting from technical product offerings to result- and use-oriented PSS.

This paper is structured as follows: In section 2 related work on PSS as well as on user integration is explained. Section 3 describes sampling, data collection and analysis. Based thereon the results of the case study are described in detail in section 4. Finally, conclusions, implications and an outlook on future work are derived in section 5 .

\section{Related work}

\subsection{Product-Service Systems}

Product-service systems (PSS) are integrated offerings of products and services. Producers extending their core product business by providing an integrated solution bundle to their customers can distinguish their offerings easier from technically similar rival products [2, p. 1543]. GOEDKOOP ET AL. [3, p. 18] define a Product-Service System as “(...) a marketable set of products and services capable of jointly fulfilling a user's need". A PSS can comprise different ratios of product and service components - either product or service components can be dominant or equally weighted [4]. Based on the relative shares of product- and service components three categories of PSS can be distinguished [1], which are illustrated in Fig. 1. The three types of PSS are described in the following:

Product-oriented PSS: The physical product is sold to the customer in a combination with services such as maintenance, recycling and customer trainings which guarantee the functionality and a long use-cycle. Main aspects in the development of this PSS type are the creation of a durable product to minimize service costs and optimize the product end-of-life through recycling and reusable parts.

Use-oriented PSS: In this case the product is not owned by the customer anymore but is made available (e.g. through leasing) for customer-usage through the producer. High rates of usage as well as a long lifecycle of their products are the main goals for companies offering these product-service-systems. 
Result-oriented PSS: This is the most complex type of a PSS, selling a desired result in place of a product (e.g. the offering of washed clothes instead of selling washing machines). The ownership as well as the decision of technology, maintenance, disposal etc. stays with the producer. Thus, the development of this PSS has to focus on the changed business model for which the consumer only pays per obtained output.

Firms can move from one type of PSS offering to another by changing the relative share of product and service components according to user requirements [1], [3], [5].

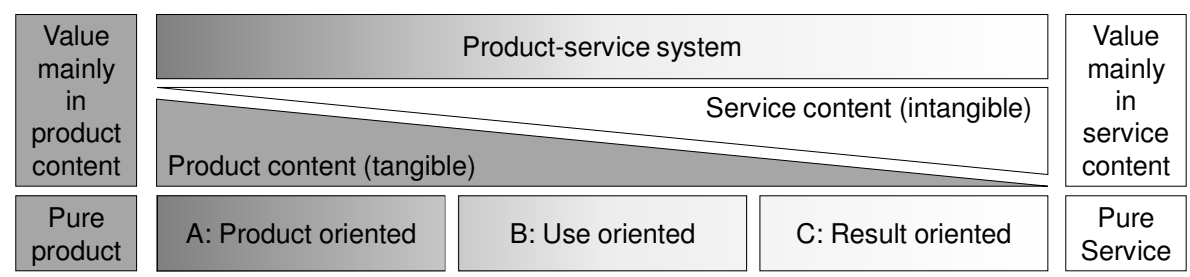

Fig. 1. Main and subcategories of PSS [1]

\subsection{User integration as an instrument for enhancing firm service orientation}

For a long time producers have been regarded as the principal source of innovation. Their motivation to innovate is driven by monetary profit expectations from selling products and services. Within the last decades literature on user innovation has identified users as an important complementary source of innovation. Users' motivation to innovate is driven by their own needs and expected benefits from using the innovation themselves rather than monetary profit expectations [6]. Users (located outside of the company's boundaries) hold distinct knowledge-sets, which are complementary to corporate knowledge. Users hold detailed need-knowledge focused around and developed by their own usage of products, whereas producers rather hold in-depth technical solution knowledge build by systematic R\&D processes. User integration in corporate innovation has been found to enhance firm innovation performance [7]. The integration of user knowledge is especially important for developing PSS. Through integration of service components, PSS are tied to the actual user experience. User knowledge is particularly important for the development and provision of PSS-service components [8].

\subsection{Research objective and questions}

The primary objective of this paper is to connect firm service orientation and PSS development to the integration of user knowledge and to the structure of product portfolio. Thereby we address three main research questions:

- Which types of PSS are offered by companies in the German machine and plant manufacturing industry and how can they be classified?

- How do companies integrate user knowledge to strengthen their service orientation and to develop PSS?

- How does product architecture (standardized, modularized or individualized products) affect service orientation? 


\section{Method}

In line with our exploratory research objective and design, we use a qualitative case study approach [9]. Within the sections 3.1 and 3.2 we describe our strategy for sampling, data collection and data analysis. In 3.3 we provide a detailed description of our final sample.

\subsection{Sampling}

We study PSS and service orientation within the context of the German machine and plant manufacturing industry. Since machines or plants are often complex and developed specifically for the customer, they also require intensive advisory which might point towards a tendency for developing a higher service orientation and a suitable context for studying PSS development. Within the industrial focus, we study $n=7$ in-depth case studies varying in business size, as well as in their product- and service-portfolio. ${ }^{1}$

\subsection{Data collection and analysis}

For the case studies we collected data from multiple data sources. We conducted interviews with firm employees and triangulated the interview data with complementary secondary data on the companies' product / service portfolio and strategy. The interviews were conducted in April 2014 during the Hannover Messe. The Hannover Messe is the world leading trade fair for industrial technology ${ }^{2}$. Companies were contacted before the trade fair to identify suitable employees for the interviews. The interview participants included sales representatives, service personnel, managing directors, product manager as well as development representatives. Interviews took from 25-45 min. and were conducted using a semi-structured interview guideline guiding through the main topics of interest for the study. At the beginning of the interview, all study participants were informed about the purpose of the study and were guaranteed anonymity to enhance trust and foster unbiased answers [10].

We triangulated the interview data with secondary data to (1) get complementary insights and to (2) cross check / validate data from the interviews. We analyzed the companies' product and service portfolio using company data taken from company websites and brochures. Furthermore, for all companies we collected data on number of employees, industries covered, and revenues from Hoppenstedt / Bisnode ${ }^{3}$ and conducted a press research using the database factiva ${ }^{4}$ to gather available insights on the

\footnotetext{
${ }^{1}$ A description of the sample is provided in section 3.3.

${ }^{2}$ http://www.hannovermesse.de/; Hannover, Germany. retrieved on: August 2, 2016

${ }^{3} \mathrm{http}: / / \mathrm{www} \cdot$ bisnode.com/ retrieved on: August 2, 2016

${ }^{4}$ Factiva is a business information and research tool owned by Dow Jones \& Company. Factiva products provide access to more than 32,000 sources (such as newspapers, journals, magazines, etc.) from nearly every country worldwide in 28 languages, including more than 600 continuously updated newswires (http://new.dowjones.com/products/factiva/).
} 
companies's current and future service and PSS strategy. Table 1 provides an overview of all data sources used and their purpose for our study.

Table 1. Overview of data sources

\begin{tabular}{lll}
\hline Data Source & Detailed data formats & Purpose and dimensions covered \\
\hline Interviews & $\begin{array}{l}\text { Audio files, transcripts, } \\
\text { protocols }\end{array}$ & $\begin{array}{l}\text { Main data source: Service orientation, } \\
\text { customer integration }\end{array}$ \\
Company sources & $\begin{array}{l}\text { Company websites, com- } \\
\text { pany brochures }\end{array}$ & $\begin{array}{l}\text { Complementary data: Service strategy, } \\
\text { product and service portfolio }\end{array}$ \\
Press articles & Articles from database & $\begin{array}{l}\text { Complementary data: Current and future } \\
\text { service and PSS strategy }\end{array}$ \\
& Factiva & Control variables: \# of employees, reve- \\
Company data & Profiles from database & Conteg \\
& Hoppenstedt / Bisnode & nue, industries covered, year established \\
\hline
\end{tabular}

We used case displays in order to structure our data and to compare the cases across the dimensions relevant for our study [11]. Within these displays we consolidated all three data sources to get an extensive picture of our data set. The relevant dimensions included in the comparative analysis were: (1) Primary industry, (2) Product portfolio, (3) Service portfolio, (4) Service infrastructure, (5) Service orientation, (6) Instruments of customer integration.

\subsection{Sample description}

Our final sample comprises seven detailed cases / companies from the German machine and plant manufacturing industry. Following the maximum variation sampling approach our final sample includes companies varying with regard to (1) company size, (2) complexity of product portfolio, and (3) depth and breadth of service offerings.

Table 2. Overview of sample description

\begin{tabular}{|c|c|c|c|}
\hline $\begin{array}{l}\text { Case } \\
\#\end{array}$ & Company description & $\begin{array}{l}\text { \# of employees } \\
2014\end{array}$ & $\begin{array}{l}\text { Revenues EUR } \\
\text { mn } 2014\end{array}$ \\
\hline 1 & $\begin{array}{l}\text { Design and manufacture bespoke systems for all } \\
\text { types of Plastic Extrusions }\end{array}$ & 10 & 1.1 \\
\hline 2 & $\begin{array}{l}\text { Mechanical engineering and automation solutions } \\
\text { for panel builders and manufacturers of electric } \\
\text { enclosures }\end{array}$ & 50 & $7.5^{1}$ \\
\hline 3 & $\begin{array}{l}\text { Leader in metal and plastic forming equipment, } \\
\text { offers presses, automation, dies, process know- } \\
\text { how and services for the entire metal forming in- } \\
\text { dustry and lightweight vehicle construction }\end{array}$ & $56^{1}$ & n.a. \\
\hline 4 & $\begin{array}{l}\text { Developer of special purpose machinery, includ- } \\
\text { ing development, manufacturing and installation }\end{array}$ & 60 & $6.2^{1}$ \\
\hline 5 & $\begin{array}{l}\text { Provider of industrial cleaning technology - focus } \\
\text { on automotive industry }\end{array}$ & 120 & n.a. \\
\hline 6 & $\begin{array}{l}\text { Development, construction and realization of au- } \\
\text { tomation systems }\end{array}$ & 220 & 32.0 \\
\hline 7 & $\begin{array}{l}\text { Manufacturing of the full range of industrial laun- } \\
\text { dry machinery }\end{array}$ & $713^{2}$ & $189.9^{2}$ \\
\hline
\end{tabular}

\footnotetext{
${ }^{1}$ as of $2013^{2}$ as of 2011
} 
With regard to company size, we used the EU definition ${ }^{5}$. Following this classification our sample contains three large, two medium-sized, one small and one micro enterprise. With regard to the product portfolio the companies' products range from special purpose machinery and working tools to automation systems in a wide field of applications such as polymer processing, washing and laundry or plastic and metal forming technology. With regard to the service portfolio, all sampled enterprises offered varying degrees of standard services such as planning, maintenance and consulting. In addition, specialized services such as optimization, programming, mechanical and electrical engineering or training are offered.

\section{$4 \quad$ Results}

To address our research questions, the outcomes section is structured as follows: In 4.1 we develop an index for service orientation based on interview data and secondary data sources. We use the companies' scoring on this index to allocate the companies within different categories of PSS depending on their service orientation. In section 4.2, we investigate how customer integration in PSS development can favor service orientation as well as the integration of products and services in PSS. In section 4.3 we identify and analyze product architectures affecting firm service orientation.

\subsection{Service orientation and PSS development}

Based on our triangulated data sources we composed an index for service orientation to assess our cases' service orientation and PSS offering. The index is composed based on data within three dimensions: (1) Rating of service infrastructure, (2) Rating of service portfolio, and (3) Assessment of current and future service strategy (weighted double). The index can take values from 1 to 7 . A value of 1 indicates a low service orientation and an offering tailored around very product oriented PSS. A value of 7 indicates a very high service orientation and an offering tailored around result-oriented PSS. The detailed measures and composition of the index are explained in the following:

1. Assessment of service infrastructure. Based on secondary data from company websites, brochures and materials the service infrastructure of the respective case was rated. In order to assess the service infrastructure, we searched for indicators such as channels through which customers can get in contact with the company (e.g. contact persons, $24 \mathrm{~h}$ hotlines), service personnel (e.g. employees working in sales and services) or service network (national / international facilities). The rating is relative, i.e. it compares each case to the rest of the sample.

2. Assessment of service portfolio. Based on secondary data from company websites and brochures we assessed the breadth of the service portfolio. We listed and described the offered services for each company and assessed the portfolio of each case relative to the rest of the sample.

${ }^{5}$ European Commission. The new SME definition. User guide and model declaration. http://bookshop.europa.eu/en/the-new-sme-definition-pbNB6004773/ 
3. Assessment of service strategy (double-weighted in index). Based on data from interviews and press research, we assessed the company's current and future service strategy. Within the interviews, we asked for relevance of services for the business, the integration of products and services, and the company's awareness and application of (result-oriented) PSS approaches. Within press releases we looked for future plans related to services (e.g. planned expansion of service portfolio, planned future focus on service orientation, services as growth potential).

We used companies' scoring on the service orientation index to allocate the cases across the three types of PSS offerings [1]. The results of this analysis show that the cases within our sample vary with regard to the PSS strategy they are following.
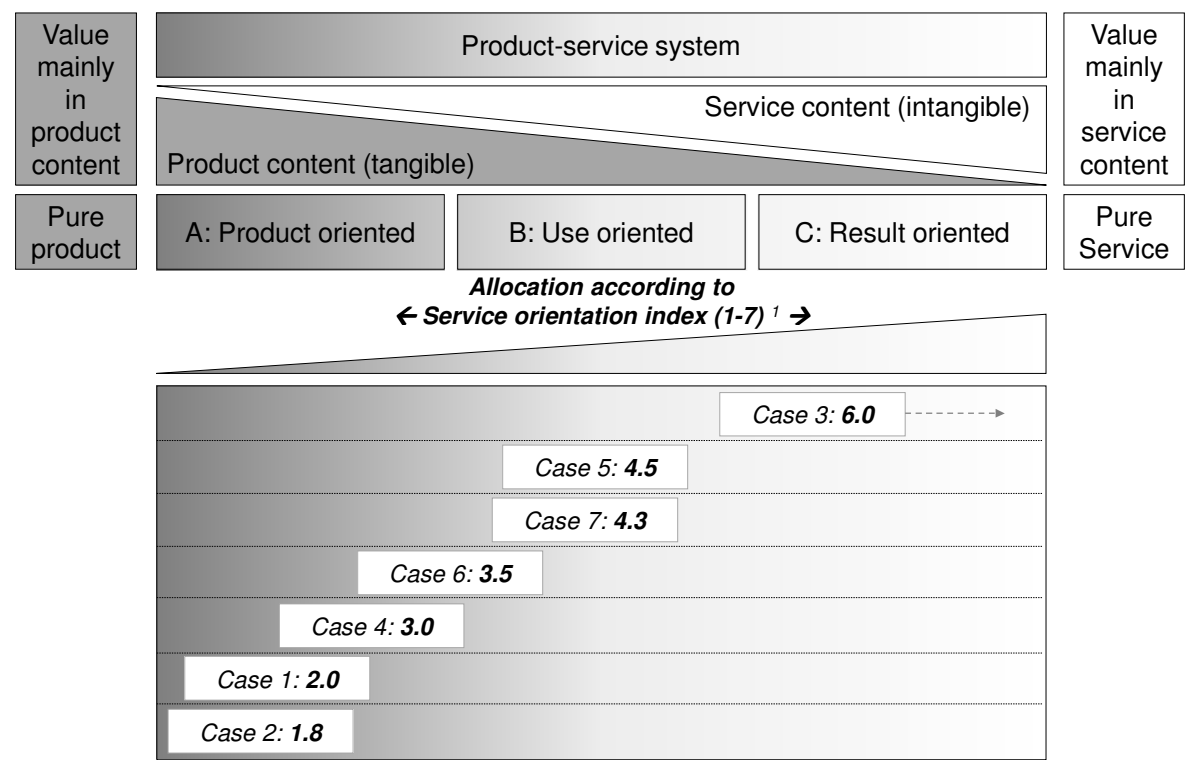

1 Schematic figure - not true to scale.

Fig. 2. Own illustration based on TUKKER [1]. Schematic illustration of PSS / Service orientation within the sample. The seven cases vary from a rating of 1.8 to 6.0.

Fig. 2 depicts the distribution of the seven cases along the service orientation index and across the three PSS categories. With regard to their scoring on the service orientation index the cases vary in their ratings from 1.8 to 6.0. The sample shows a great variance but is skewed to the lower end. So far, the sample companies do not follow "radical" result-oriented PSS strategies, such as pay-per-outcome approaches. Also, only the two companies scoring highest on the index plan to re-evaluate and improve their service strategies and portfolio in the near future. The cases with a rather low service orientation build their business around their product portfolio. Services are standardized and available on demand for the customer. The relevance of services for business development is perceived as rather low. Such a service orientation is for example characterized by the following statement of company 2 : 
Citation Case 26: "Basically, we build the machines. Own development and own construction and after that, if the machines are sold, we offer the normal support. The customer has a question, calls us and we answer his questions. Furthermore, we offer the delivery of spare parts."

A high scoring on the service orientation index is characterized by a (relatively) high relevance of services for business development. Services are perceived as important complements to the company's product portfolio. These companies invest in service infrastructure and personnel. Such an orientation can be found in company 7:

Citation Case 7: "[...] Furthermore it is normal that, if we sell a complete laundry to the customer or perform adaptions at his laundry, we take his business environment into account. Usually, our sales personnel has direct contact to the customers and conducts a review of the situation. They take measurements of the space, make suggestions through technical drawings and by that we develop a customer-specific offer."

\subsection{User integration as a means for enhancing service orientation}

Since the provision of services is closely tied to the actual user experience, customer integration and service orientation are expected to be closely related. We argue, that user orientation and the integration of user knowledge are essential when firms intend to strengthen their service orientation to move from product-oriented to use- or resultoriented PSS offerings. Within our interviews, we found that those cases offering a high degree of service orientation (Cases 3,5,7) also build and maintain strong ties to their customers and integrate them intensively in the development of their offerings. Firms characterized by a high degree of service orientation gather user knowledge to develop new products and services, as indicated by the following citation.

Citation case 7: „Very often we have a direct discussion with the customer [...]. There we receive feedback from the customer - of course, we talk about the new machines, maybe there is still need for optimization, which then is incorporated in our construction. Furthermore, the entire process and general concerns of the customers are discussed. For example the customers says that there is a problem for which no manufacturer offers a solution, but where they see a demand for new developments."

Firms showing a relatively high level of service orientation know about the relevance and value of both external user and internal producer knowledge. These companies often know implicitly or explicitly about the value of user knowledge that is distinct from the company's internal knowledge base. User knowledge is perceived as problem-oriented situation specific knowledge focused around actual needs. Firm knowledge is perceived as the source for potential solutions for addressing user needs.

Citation case 6: "[...] we prepare a concept for a mounting-system and the customer describes what shall be mounted, but does not prescribe how it has to be mounted".

\footnotetext{
${ }^{6}$ Interviews were conducted in German. Citations used have been translated for this paper.
} 


\subsection{Developing integrated PSS - The influence of the product architecture on service orientation}

Within our study we explicitly searched for factors enhancing and hindering service orientation within the cases. We found that service orientation within a company needs to be aligned with a firm's product architecture and strategy. Within our sample, companies follow three basic strategies with regard to their product portfolios: Standardized products, modularized products, and individualized products. These different strategies have an impact on the cases' service orientation. Standardized, as opposed to individualized or modularized product portfolios only require little advisory in pre- and aftersales phases. We identified individualized or modularized product portfolios as being positively related to service orientation. Individualized (as opposed to standardized) and modularized product architectures require extensive advisory and a high service orientation in the pre-sales phase, as indicated by the following statements.

Citation Case 5 (Individualized products): „That is the main focus of our company. We don't have off-the-rack systems, rather each machine we sell is to 95\% a machine, which we haven't built before. Of course similar - the system is similar - but not in that form, not with the same parts. We have parts that have the size of mobile phones; others are as big as ship's engines. That's why in our company no machine is equal."

Citation Case 7 (modularized products): „Generally, we have basic modules. We implemented it in that way that our machines - if we develop new ones - are designed in a modular manner and sometimes, equal parts of previous machines are used. By that, one can say that no laundry is similar to another one; rather such companies usually grow over time. Normally they begin in a very small manner and then add further parts. Thus, we really have to satisfy these specific requirements."

The companies in the sample characterized by a standardized product portfolio only offer a few add on product-oriented services such as maintenance and warranty.

\section{$5 \quad$ Conclusions and future work}

This study uses a qualitative case study to explore service orientation of companies in the German machine and plant manufacturing industry and connect it to product architecture and the integration of user knowledge. By extending their products through additional services, companies in the industry shift from manufacturing technical products towards offering integrated product-service systems (PSS). Our results show that service orientation varies greatly across the cases of our sample. We find that service orientation is related to firm product architecture and that the integration of user knowledge can serve as an instrument for strengthening service orientation. Our study has important implications for the management of PSS in the German machine and plant manufacturing industry. First, showing that service orientation is affected by the structure of product portfolio emphasizes the relevance of aligning and integrating a firm's product and service strategy for successful PSS development. Especially customer-specific machines and plants require a higher level of service orientation than standardized products over the entire lifecycle. Both components need to be adapted to 
fit each other. Also, we show that user integration can be used as an important instrument for strengthening service orientation and PSS development within firms. User requirements and user knowledge can be used to catalyze the transition from product- to use- or result-oriented PSS. In this paper we analyzed seven in-depth cases from the German machine and plant manufacturing industry. In order to draw further conclusions a larger sample-size with specific questions regarding user integration shall be conducted. Furthermore, in future research the identified potentials (user integration, product architecture) should be integrated into an adequate PLM approach, considering service provision, to foster companies to offering integrated solutions through PSS.

Acknowledgment. We thank the German Research Foundation (DFG) for funding this work as part of the collaborative research centre 'Sonderforschungsbereich 768 - Managing cycles in innovation processes' (SFB 768).

\section{References}

1. Tukker, A.: Eight types of product-service system: eight ways to sustainability? Experiences from SusProNet. In: Business Strategy and the Environment (2004), Vol. 13 (4), pp. 246-260.

2. Baines, T. S.; Lightfoot, H. W.; Evans, S.; Neely, A.; Greenough, R.; Peppard, J.; Roy, R.; Shehab, E.; Braganza, A.; Tiwari, A.; Alcock, J. R.; Angus, J. P.; Bastl, M.; Cousens, A.; Irving, P.; Johnson, M.; Kingston, J.; Lockett, H.; Martinez, V.; Michele, P.; Tranfield, D.; Walton, I. M.; Wilson, H.: State-of-the-art in product-service systems. In: Proceedings of the Institution of Mechanical Engineers, Part B: Journal of Engineering Manufacture 221 (2007), Nr. 10, pp. 1543-1552.

3. Goedkoop, M.; van Halen, C.; te Riele, H.; Rommens, P.: Product service systems, ecological and economic basics. The Hague: Ministry of Housing, Spatial Planning and the Environment, Communications Directorate; Distributiecentrum VROM 1999.

4. Abramovici, M.; Schulte, S.: Lifecycle Management für hybride Leistungsbündel (HLB). In: wt Werkstattstechnik online (2006), No. 7/8, pp. 467-471.

5. Spath, D.; Demuß, L.: Entwicklung hybrider Produkte - Gestaltung materieller und immaterieller Leistungsbündel. In: Bullinger, H.-J.; Scheer, A.-W. (Hrsg.): Service Engineering: Entwicklung und Gestaltung innovativer Dienstleistungen. 2., vollständig überarbeitete und erweiterte Auflage (2006). Springer, Berlin, pp. 463-502.

6. von Hippel, E.: The sources of innovation (1988). Oxford University Press, New York.

7. Chatterji, A.K.; Fabrizio, K.: Ho do product users influence corporate invention. In: Organization Science (2012), Vol. 23(4), pp. 971-987.

8. Schmidt, D.M.; Preissner, S.; Hermosillo Martinez, J.A.; Quiter, M.; Mörtl, M.; Raasch, C.: Integration of user knowledge across the lifecycle of integrated product-service systems - An empirical analysis of the relevance for PSS development and management. In: ICED International Conference of Engineering Design (2015), Milan.

9. Yin, R.K.: Case study research: Design and methods (2013). Sage Publications, Los Angeles.

10. Flick, U.: An introduction to qualitative research (2009). Sage Publications, Los Angeles.

11. Miles, M. B., Huberman, A. M., \& Saldana, J.: Qualitative Data Analysis: A Methods Sourcebook (2013). Sage Publications, Los Angeles. 